\title{
BAHAN AJAR MULTIMEDIA INTERAKTIF ILMU PENGETAHUAN ALAM SEBAGAI MEDIA PEMBELAJARAN INOVATIF Jupriyanto ${ }^{1}$, Turahmat ${ }^{2}$ \\ ${ }^{1}$ PGSD FKIP Universitas Islam Sultan Agung, jupriyanto@ unissula.ac.id ${ }^{2}$ PBSI FKIP Universitas Islam Sultan Agung, lintangsastra@unissula.ac.id
}

\begin{abstract}
ABSTRAK
Penelitian terkonsentrasi pada pengembangan bahan ajar berbentuk multimedia interaktif sebagai alternatif media pembelajaran inovatif. Penelitian ini menggunakan model four-D yang telah dimodifikasi, menjadi tahap Define (analisis materi, analisis laboratorium, dan merumuskan tujuan pembelajaran), Design (pemilihan media, pemilihan format, dan draft awal) dan Develop (validasi ahli dan uji coba). Analisis data yang dilakukan uji normalitas, uji homogenitas, dan uji beda rata-rata. Nilai validasi untuk multimedia interaktif secara rata - rata 3.72 termasuk dalam kategori valid. Hasil uji kelas kontrol menghasilkan mean 61.15 dan kelas eksperimen 88.75 dengan signifikansi hitung yang digunakan 0.004. Secara keseluruhan multimedia interaktif sangat baik dan inovatif digunakan dalam permbelajaran.
\end{abstract}

Kata Kunci : Bahan Ajar, IPA, Multimedia Interaktif, inovatif

\section{A. PENDAHULUAN}

Perkembangan ilmu pengetahuan menghendaki penguasaan dasar-dasar pendidikan yang kokoh dan penguasaan keahlian. Perkembangan ilmu pengetahuan menuntut pendidikan berlangsung lebih lama yang sesuai dengan konsep pendidikan seumur hidup (longlife education). Perkembangan teknologi dalam pendidikan akan mempermudah manusia dalam menerima informasi.

Pembaharuan yang mengiringi perkembangan zaman, membuat lembaga- lembaga kependidikan mulai menggunakan inovasi baru. Namun tidak sedikit juga yang tetap menggunakan metode dan teknik-teknik 
yang lama dimana menekankan pada metode hafalan. Satu hal yang menimbulkan kelemahan pada metode ceramah adalah keefektifan pengajaran yang sangat tergantung pada keterampilan, keahlian, dan kharisma individu pengajar. Kelemahan lainnya timbul berdasarkan fakta bahwa siswa biasanya pasif dalam belajar. Hampir seluruh waktu belajar digunakan untuk mendengarkan guru dan mencatat isi pelajaran.

Sekolah sebagai lembaga pendidikan, sangat penting dalam proses peningkatan sumber daya manusia. Program sekolah dilaksanakan secara teratur dan sistematis, dengan sarana dan prasarana yang memadai serta peran guru sebagai pembimbing akan menghasilkan pemahaman dan penalaran yang cepat bagi siswa dalam pengambilan keputusan. Keberhasilan tentunya juga sangat ditentukan oleh berbagai faktor salah satunya harus ada keterkaitan antar komponen pembelajaran yaitu tujuan, metode, media, materi, dan evaluasi pembelajaran.

Majunya ilmu pengetahuan dan teknologi merupakan suatu perkembangan yang memberikan akses terhadap perubahan kehidupan masyarakat, berbagai permasalahan yang ada dapat dipecahkan dengan penguasaan ilmu pengetahuan dan teknologi. Perubahan ini juga membawa mayarakat kedalam persaingan global yang semakin ketat, sehingga memaksa suatu bangsa harus berusaha mengembangkan dan meningkatkan kualitas sumber daya manusianya agar mampu berperan dalam persaingan global.

Pembelajaran di sekolah dengan memanfaatkan teknologi dan informasi terutama di sekolah dasar sangat rendah. Berdasarkan data Pusat Teknologi dan Komunikasi (Pustekkom) yang dimuat dalam kompas.com (2009), jumlah sekolah dasar yang mempunyai laboratorium komputer baru mencapai 10 persen. Jumlah ini jauh lebih rendah dibandingkan dengan keberadaan laboratorium komputer di jenjang sekolah menengah.

Salah satu bentuk pembaharuan pembelajaran adalah dengan menggunakan media pembelajaran yang efektif, menarik dan bermakna bagi siswa. Selain itu, bila media dirancang dan dibuat dengan baik semakin baik pula media itu dalam menjalankan fungsinya sebagai penyalur pesan, untuk topik- topik tertentu media dapat lebih 
baik daripada guru dalam menyampaikan pesan, makin baik medianya makin kecil distorsinya dan makin baik pesan itu diterima siswa.

Multimedia interaktif menyajikan materi dalam bentuk teks, gambar, audio, video, animasi serta menggabungkan link dan tool yang memungkinkan siswa beriteraksi dengan bahan ajar tersebut. Multimedia interaktif merupakan salah satu dari media pembelajaran dengan bantuan komputer yang sering disebut sebagai Computer Assisted Intruction (CAI), yaitu media pembelajaran dimana siswa belajar berhadapan dan beriteraksi secara langsung dengan komputer. Interaksi tersebut terjadi secara individual, dengan adanya link dan tool memungkinkan siswa untuk memilih materi yang kurang dimengerti.

Multimedia interaktif ini diharapkan dapat menemukan pola yang lebih efektif dalam pembelajaran, sehingga setiap materi pembelajaran dapat disajikan sedemikian rupa dan diharapkan lebih menarik, efektif dan melekat, serta hasilnya dapat diterapkan pada setiap mata pelajaran. Khususnya dapat memenuhi kebutuhan media ajar di SD untuk memaksimalkan pemanfaatan laboratorium komputer yang ada, sehingga penggunaannya dapat diterapkan pada pembelajaran selain ekstrakurikuler komputer.

Masalah yang diangkat dari hasil penelitian ini dibatasi pada permasalahan pembelajaran IPA pada materi pembelajaran pencernaan dan pernapasan, kelas $\mathrm{V}$ semester pertama berbasis multimedia dengan menggunakan media interaktif yang masih kurang dimanfaatkan. Penelitian difokuskan untuk mengembangkan Bahan Ajar Multimedia Interaktif (BAMI) pada mata pelajaran Ilmu Pengetahuan Alam dengan materi pencernaan dan pernapasan dengan memanfaatkan program Macromedia Flash 8.

Berdasarkan latar belakang, maka permasalahan yang diangkat dalam pengembangan bahan ajar multimedia interaktif ini adalah :

1. Bagaimana teknik pengembangan bahan ajar multimedia interaktif IPA dengan materi pembelajaran pencernaan dan pernapasan?

2. Bagaimana keefektifan dan kepraktisan bahan ajar multimedia interaktif yang 
inovatif?

Manfaat yang diharapkan dari pengembangan bahan ajar ini dibagi menjadi dua yaitu manfaat teoritis dan praktis. Manfaat praktis bagi guru dari penelitian pengembangan ini membantu menambahkan variasi multimedia pembelajaran yang dapat digunakan di sekolah dasar terutama mata pelajaran IPA. Selain itu manfaat praktis bagi siswa diharapkan dapat lebih mudah memahami materi pernapasan dan pencernaan pada mata pelajaran IPA lebih antusias dalam mengikuti proses pembelajaran khususnya mata pelajaran IPA.

Manfaat teoritis hasil penelitian dan pengembangan ini menjadi kontribusi dalam melengkapi penelitian yang berhubungan dengan multimedia pembelajaran. Pengembangan bahan ajar pembelajaran IPA ini diharapakan dapat menambah dan memperkaya koleksi bahan ajar pembelajaran yang telah dimiliki dan dikembangkan. Selain itu bagi pembaca secara umum, dapat menambah pengetahuan tentang IPA berbentuk multimedia interaktif dan cara mengembangkannya.

Pengembangan bahan ajar yang dilakukan dalam penelitian ini adalah pengembangan produk berupa bahan ajar multimedia interaktif. Multimedia interaktif yang dikembangkan dalam penelitian ini merupakan kombinasi teks, seni, suara, gambar, animasi, dan video yang disampaikan dengan komputer atau dijalankan secara digital dan dapat disampaikan dan atau dikontrol secara interaktif.

Penyusunan bahan ajar yang dilakukan menggunakan software Macromedia Flash 8. Adobe flash CS4 profesional adalah merupakan suatu program animasi yang digunakan untuk pembutan animasi 2D dapat dibuat seperti membuat interactive animation, game, company profile, persentasi, video clip, movie, web animasi, dan aplikasi animasi lainnya.

\section{B. PEMBAHASAN}

\section{Metodologi Penelitian}

Pendekatan penelitian yang digunakan dalam penelitian ini adalah penelitian dan pengembangan (research and development). Penelitian dan pengembangan digunakan untuk menghasilkan produk multimedia interaktif. Model pengembangan yang digunakan untuk mengembangkan bahan ajar multimedia interaktif dalam 
penelitian adalah model Four-D modifikasi dari model Thiagarajan, Semmel, and Semmel. Modifikasi yang dilakukan adalah penyederhanaan model menjadi tiga tahap, yaitu pendefinisian (define), perancangan (design), dan pengembangan (develop). Untuk tahap penyebaran (disseminate) tidak dilakukan.

Tahap-tahap pengembangan Bahan Ajar Multimedia Interaktif (BAMI) dalam penelitian dijabarkan sebagai berikut;

\section{a. Tahap pendefinisian (Define)}

Tahap pendefinisisan bertujuan untuk menetapkan dan mendefinisikan kebutuhan kebutuhan pembelajaran dengan menganalisis tujuan dan batasan materi. Kegiatan pada tahap pendefinisian meliputi:

1) Analisis Kepustakaan

Analisis kepustakaan meliputi kurikulum yang dilakukan untuk menentukan masalah dasar yang diperlukan dalam pengembangan bahan pelajaran. Pada tahap analisis kepustakaan dilakukan telaah kurikulum mata pelajaran IPA kelas V dengan teori belajar yang relevan untuk mendapatkan deskripsi pola pembelajaran yang dianggap sesuai dan ideal untuk dikembangkan.

2) Analisis Kompetensi

Analisis kompetensi yang dilaku- kan yaitu menelaah mengenai standar kompetensi, kompetensi dasar, silabus dengan teori yang relevan. Analisis siswa dilakukan dengan Analisis kompetensi dilakukan untuk identifikasi keterampilan-keterampilan utama yang harus dimiliki siswa setelah melaksanakan materi pencernaan dan pernapasan sesuai dengan kompe- tensi dasar. Dalam tahap ini ditentukan indikator belajar yang ingin dicapai sesuai dengan kompetensi dasar.

3) Analisis Materi

Analisis materi dilakukan untuk mengidentifikasi, merinci, dan menyusun secara sistematis konsep-konsep yang relevan yang akan diajarakan berdasarkan analisis kurikulum. Analisis materi mengacu pada standar kompetensi, kompetensi 
dasar, dan silabus. Analisis

materi dilakukan melalui diskusi guru kelas V. Tahap analisis materi, peneliti melakukan kajian terhadap konsep-konsep atau teori-teori yang berkenaan dengan pembuatan bahan ajar interaktif yang akan dikembangkan. Kajian yang dilakukan meliputi kajian terhadap kurikulum untuk mata pelajaran Ilmu Pengetahuan Alam kelas V SD semester I pencernaan dan pernapasan pada manusia.

4) Merumuskan tujuan

pembelajaran

Merumuskan tujuan

pembelajaran yang operasional dan dapat diukur berdasarkan hasil analisis kompe- tensi dan analisis materi. Tujuan pembelajaran tersebut merupakan acuan dalam merancang atau menyusun tes dan rancangan bahan ajar pembelajaran multimedia interaktif. Analisis materi dan analisis kompetensi pembelajaran sebagai rujukan dalam menentukan tujuan pembe- lajaran yang akan dicapai. Tujuan pembelajaran yang akan dicapai sebagai berikut.

a) Menyebutkan secara urut alat pernapasan dan pencernaan pada manusia

b) Menjelaskan proses pernapasan dan pencernaan pada manusia

c) Menjelaskan fungsi organ pernapasan dan pencernan pada manusia

\section{b. Tahap Perancangan (design)}

Tahap ini bertujuan merancang atau mendesain awal BahanAjar Multimedia Interaktif (BAMI). Berdasarkan pada tahap pendefinisian maka peneliti menyusun Draft I produk yaitu BAMI yang akan dikembangkan. Pada tahap ini langkah-langkah pembuatan media ajar multimedia interaktif dirancang dengan didasarkan pada analisis materi, analisis kompetensi, dan tujuan pembelajaran yang akan dilakukan. Penyusunan Draft I dengan memperhatikan faktor ketertarikan 
dan keaktifan siswa dalam menggunakan bahan ajar. Draft ini selanjutnya direview atau divalidasi oleh pakar materi dan pakar media. Hasil dari review ini digunakan sebagai masukan- masukan untuk penyempurnaan Draft I tersebut. Berikut merupakan Draft I BAMI yang pada tahap selanjutnya direview dan divalidasi oleh ahli materi dan ahli multimedia.

c. Tahap Pengembangan (develop) Tujuan pengembangan perang- kat pembelajaran adalah untuk menghasilkan draf perangkat pembelajaran. Kegiatan pada tahap pengembangan meliputi validasi ahli dan uji coba. Revisi produk dilakukan dalam tahap pengembangan untuk mendapatkan produk yang dapat diujicobakan.

Tahap pengembangan produk dimulai dengan pendefinisan analisis keterbutuhan materi bahan ajar. Draft I dirancang setelah terbentuk analisis kebutuhan dengan mempertimbangkan tujuan pembelajaran dan indikator pembelajaran. Langkah selanjutnya dengan menvalidasi Draft I oleh pakar multimedia dan ahli materi.
Hasil validasi menunjukkan Draft I multimedia termasuk ke dalam kriteria baik dengan catatan perlu adanya revisi produk.

\section{Hasil Penelitian}

Produk akhir dari penelitian dan pengem- bangan ini adalah bahan ajar IPA berbentuk multimedia interaktif. Pengembangan produk yang dilakukan dengan beberapa tahapan. Pro- duk akhir yang dihasilkan dalam pengembangan ini adalah Bahan Ajar Multimedia Interak- tif (BAMI) yang dapat digunakan di sekolah dasar kelas V.

Secara umum validator menyatakan BAMI termasuk dalam kategori baik tetapi dengan sedikit revisi yang perlu dilakukan. Beberapa komponen dalam BAMI harus direvisi. Revisi menu utama terdapat pada perubahan font judul multimedia. Perubahan selanjutnya terdapat pada simbol gambar setiap menu. Perubahan selanjutnya terdapat pada perubahan subtittle.

Revisi yang disarankan validator terdapat penambahan apersepsi dan penambahan author. Apesepsi dimaksudkan untuk menstimulus pengguna agar tertarik dengan 
multimedia interaktif. Author berisikan nama pembuat multimedia yang bertujuan untuk menghindarkan dari plagiat media oleh pihak lain. Secara keseluruhan, validator memberikan nilai 3.72 termasuk dalam kategori baik.

Uji coba data menghasilkan data dengan validitas soal semua soal yang terdapat dalam multimedia interaktif valid. Tingkat reliabilitas soal 0.942 lebih besar dari 0.05 dinyatakan reliabel dalam kategori sangat tinggi. Data pada multimedia interaktif dinyatakan valid dan reliabel. Uji coba terbatas menghasilkan nilai rata-rata siswa 76.85 . Tingkat ketertarikan siswa sangat tinggi yaitu 4.20. Hasil wawancara dengan guru pada uji coba terbatas menunjukkan multimedia interaktif efektif digunakan dalam pembelajaran dengan sarana komputer yang memadai.

Uji coba luas dilakukan pada kelas eksperimen dan pembanding pada kelas kontrol. Kedua kelas berdistribusi secara normal dan heterogen. Terdapat perbedaan rata-rata hasil tes yang dilakukan dari kedua kelas tersebut. Rata-rata kelas eksperimen 88.75 dan rata-rata kelas kontrol 61.15 sehingga BAMI lebih baik dan efektif digunakan dalam pembelajaran. Produk akhir dari penelitian dan pengembangan ini adalah bahan ajar IPA berbentuk multimedia interaktif. Multimedia interak- tif yang dihasilkan membahas materi tentang pencernaan dan pernapasan serta memuat berbagai menu multimedia interaktif.

\section{SIMPULAN}

Pengembangan multimedia interaktif terdiri atas tiga tahap, yaitu tahap pendefinisian, tahap perencanaan, dan tahap pengembangan multimedia interaktif. Tahap pendefinisian dilakukan dengan menganalisis materi pelajaran, observasi labolatorium komputer, analisis tujuan pembelajaran, dan analisis indikator. Tahap perencanaan dilakukan dengan merancang Draft I BAMI yang selanjutnya divalidasi dan direview oleh pakar multimedia dan ahli materi. Tahap pengembangan dilakukan dengan merevisi Draft I menjadi Draft II dengan mengujikannya secara terbatas dan luas. Hasil pengembangan akan terbentuk produk akhir Bahan Ajar Multimedia Interaktif (BAMI).

Bahan Ajar Multimedia Interaktif valid, praktis, dan efektif serta layak digunakan sebagai sumber belajar. Hal ini ditunjukkan dari hasil validasi 3.72 
termasuk dalam kategori baik. Hasil dari uji coba terbatas menunjukkan skor ketetarikan siswa 4,5 masuk ke dalam kategori sangat baik dan skor uji coba luas adalah 4,6 juga masuk ke dalam kategori sangat baik. Nilai test yang diperoleh dalam uji coba luas pada kelas eksperimen 88.75 dengan pembanding kelas kontrol 61.15. BAMI efektif digunakan dalam pembelajaran.

Produk akhir multimedia interaktif disarankan dapat digunakan pada pembelajaran IPA di sekolah dasar. Sarana dan prasarana sangat dibutuhkan seperti perangkat komputer sehingga siswa dapat melakukan kegiatan pembelajaran interaktif yang menyenangkan secara mandiri. Pengembangan lebih lanjut dari produk ini adalah pengembangan multimedia interaktif untuk mata pelajaran IPA maupun mata pelajaran lainnya. Selain itu, pengembangan multimedia interaktif juga dapat dikembangkan untuk kelas tinggi maupun kelas rendah.

$$
\text { Pemilihan gradasi warna }
$$
menentukan ketertarikan siswa terhadap multimedia yang ditampilkan. Penyesuaian warna yang ditentukan dengan karakteristik siswa Sekolah Dasar menjadi bahan pertimbangan dalam pengembangan multimedia interaktif. Pemilihan animasi yang sederhana juga mempengaruhi ketertarikan siswa terhadap multimedia interaktif.

Pemilihan sekolah yang memiliki labolatorium komputer yang memadai juga menjadi pertimbangan dalam penelitian dengan meng- gunakan multimedia interaktif. Banyak seko- lah yang memiliki labolatorium tetapi kurang dimanfaatkan dengan baik. Sebaliknya banyak guru dan siswa yang terampil mengoperasikan komputer tetapi kurang didukung dengan fasilltas komputer yang memadai.

\section{DAFTAR PUSTAKA}

Kompas. 2009. Pustekkom. Pembelajaran ICT di Tingkat SD Masih Rendah. www. edukasi.kompas.com. Diakses tanggal 27 Juli 2014.

Mbulu, Josep \& Suhartono. 2004. Pengembangan Bahan Ajar. Malang: Elang

Nusir, Sawsan. 2012. Studiying the Impact of Using Multimedia Interactive Programs at Children Ability to Learn Basic Math Skills. Journal of 
Acta Didactica Napocensia,

Volume 5 Number 2 May

2012. Halaman 74-75

Republika. 2013. Perpusnas : Minat

Baca Masyarakat Indonesia

Masih Rendah.

www.republika.com. Diakses

pada tanggal 12 Januari 2014

Rusman, 2005. Pengembangan

Kurikulum Model Desain

Sistem Pelatihan Berbasis

Kompetensi. Jurnal Teknologi

Pendidikan Edutech. 2, (2).

33-39

Steketee, Carole. 2006. Modelling

ICT integration in teacher

education courses using

distributed cognition as a

framework. University of

Notre Dame Australia:

Australasian Journal of

Educational Technology.

Volume 6 